\title{
THE OPSONO-CYTOPHAGIC REACTION OF THE BLOOD IN PERTUSSIS ${ }^{1}$
}

\author{
By WILLIAM L. BRADFORD AND BETTY SLAVIN 2 \\ (From the Departments of Bacteriology and Pediatrics, University of Rochester School of \\ Medicine and Dentistry and the Strong Memorial and Rochester Municipal \\ Hospitals, Rochester, New York)
}

(Received for publication April 26, 1937)

Investigations of humoral immunity in pertussis have been chiefly directed toward studies relating to specific agglutinins and complementfixing antibodies. One direction which recent work has taken concerns the study of the opsonocytophagic reaction of the blood. As the name implies, this reaction is a test for the opsonizing antibody in the serum as well as for the phagocytosing power of the leukocytes. Whole blood may be used, as pointed out by Veitch (1), and this method has been successfully applied by Huddleson and his coworkers (2) in undulant fever. The results of their studies stimulated us to investigate the reaction in pertussis, particularly in regard to the therapeutic effect of intravenously or intramuscularly injected immune blood (3). While the work was in progress, it was learned that Kendrick (4) had reported observations on the reaction made during the course of pertussis, and in animals before and after injection of suspensions of $H$. pertussis and of other organisms. She suggested that the reaction might be useful in studying immune processes in pertussis.

Singer-Brooks and Miller (5) have recently described their experience with the reaction and have presented the results obtained from observations made during the course of the disease. They have been particularly interested in the reaction of vaccinated children.

This report deals with observations of the reaction in children during the course of pertussis; in children with positive and with negative histories of the disease; and in mothers and their newly-born infants.

1 This investigation was aided, in part, by a grant from the Committee on Therapeutic Research, Council on Pharmacy and Chemistry, American Medical Association.

2 Working under a grant from the Fluid Research Fund of the University of Rochester.

\section{METHODS AND MATERIALS}

Freshly isolated strains of $H$. pertussis were used to produce antigens. In each instance they were found to be hemolytic on the modified Bordet-Gengou medium; were morphologically of the coccoid-bacillary type; were virulent for mice ; produced necrotic lesions when injected intradermally into guinea pigs in dosages of $0.05 \mathrm{cc}$. of a suspension containing one billion organisms per cc.; and were agglutinated by Phase I antiserums but not by Phase IV antiserums. Accordingly, by these criteria, the strains were of the virulent or Phase I type.

When the strains revealed any change from Phase I characteristics, their use was discontinued and newly isolated ones were substituted. Antigens were prepared every two to four weeks and were kept in the ice box at $4^{\circ} \mathrm{C}$. during the period used.

The medium used consisted of (a) a potatoglycerine-agar base, and $(b)$ defibrinated sheep's blood.

The base consisted of the following ingredients : peeled potato, 500 grams ; glycerin, U.S.P., 40 cc. ; Bacto-agar, 120 grams; sodium chloride, C.P., 21.5 grams ; distilled water, 4,000 cc.

It was prepared as follows. The water and glycerin were mixed. The sliced potatoes were wrapped in gauze and suspended in one-half the volume of water and glycerin mixture, and boiled until soft. The potatoes were removed and the liquid allowed to cool. The salt and the agar were then added and the mixture allowed to stand for 15 minutes in order to saturate the agar. The mixture was then heated to dissolve the agar. The remaining water-glycerin mixture was added and the mixture brought up to volume.

The base mixture was dispensed into flasks, each containing $150 \mathrm{cc}$, and autoclaved for 25 minutes at 15 pounds pressure. 
When a fresh batch of medium was desired, a flask containing $150 \mathrm{cc}$. of this base was melted in a water bath, cooled to $45^{\circ} \mathrm{C}$. and to this amount, $30 \mathrm{cc}$. of freshly drawn defibrinated sheep's blood was added. Plates or slants were then poured as needed.

This medium was found to give satisfactory results after storage in the ice box for several days, but each batch of plates or tubes was dated and at the end of three days, the unused supply was discarded.

For the growth of subcultures from which the antigens were prepared, Bradford's gonococcus medium (6) was frequently used. This medium was prepared by melting $100 \mathrm{cc}$. of 2 per cent Douglas agar ( $\mathrm{pH} 7.6$ to 7.8). When this base had been cooled to $45^{\circ} \mathrm{C}$., $25 \mathrm{cc}$. of the sterile ascitic or hydrocele fluid, $5 \mathrm{cc}$. of sterile 20 per cent glucose, and $10 \mathrm{cc}$. of sterile defibrinated rabbit's blood were added and mixed. Plates were poured in the usual manner.

Upon this medium the majority of freshly isolated strains of $H$. pertussis grew well after a few generations of growth upon the modified Bordet medium.

The technique of determining the opsono-cytophagic reaction consisted of mixing $0.05 \mathrm{cc}$. of whole blood, obtained as it flowed freely from a small incision in the finger tip, with $0.05 \mathrm{cc}$. of a 1 to 1,000 solution of heparin in physiological salt solution. To this was added $0.05 \mathrm{cc}$. of a standard killed suspension of Phase I $H$. pertussis. This suspension was made by scraping a forty-eight hour growth of the organism from Bradford's medium into physiological salt solution. Merthiolate was added to make a final concentration of 1 to 10,000 , and the suspension was standardized to match the turbidity of a known standard suspension containing approximately ten billion organisms per cc.

The organisms were added within thirty minutes after the blood was withdrawn, the mixture was shaken and placed in a $37^{\circ} \mathrm{C}$. water bath for 30 minutes. A second shaking was done after 15 minutes of incubation. At the end of the $30 \mathrm{~min}$ ute period, without further shaking, smears were made, fixed with methyl alcohol, stained by the Giemsa method for 20 minutes, washed, dried, and examined under oil immersion.
A series of 25 consecutive polymorphonuclear leukocytes were examined and the organisms engulfed in each counted. This number of cells was selected because it was observed that the final results were not significantly altered when series of 50 or of 100 cells were counted. The cells were then classified according to the number of organisms engulfed. Three arbitrary groups were used to denote the degree of phagocytosis as follows: " none to slight," 0 to 4 organisms; "definite," 5 to 19 organisms ; " marked," 20 or more organisms. If a leukocyte was distorted or if the organisms could not be counted because of marked clumping within the cytoplasm, the cell was omitted from the series. It was noted that phenolized antigens gave lower degrees of phagocytosis than did the merthiolate-preserved ones. There was no significant difference between the degree of phagocytosis obtained when living and when merthiolate-killed antigens were tested, or when the virulent Phase I and the avirulent Phase IV antigens of the same strain were compared.

\section{RESULTS}

The reaction of the blood of 49 patients, when tested at various periods during the course of the disease, is shown in Table I. For each group

TABLE I

The opsono-cytophagic reaction of the blood during the course of pertussis

\begin{tabular}{l|c|c|c|c}
\hline \hline $\begin{array}{c}\text { Week of } \\
\text { disease }\end{array}$ & $\begin{array}{c}\text { Number } \\
\text { of } \\
\text { patients } \\
\text { tested }\end{array}$ & $\begin{array}{c}\text { Distribution of the average number of } \\
\text { cells according to the number } \\
\text { of organisms phagocytosed }\end{array}$ \\
\cline { 2 - 5 } & $\begin{array}{c}\text { 0 to 4 } \\
\text { organisms } \\
\text { "none to } \\
\text { slight" }\end{array}$ & $\begin{array}{c}5 \text { to } 19 \\
\text { organisms } \\
\text { "definite" }\end{array}$ & $\begin{array}{c}20+ \\
\text { organisms } \\
\text { "marked" }\end{array}$ \\
\hline 1 and 2..... & 13 & 2.8 & 18.0 & 4.2 \\
3 and 4..... & 15 & 1.3 & 14.5 & 9.2 \\
5 and 6..... & 12 & 0.8 & 9.5 & 14.6 \\
7 and 8..... & 9 & 0.6 & 8.6 & 15.7 \\
\hline
\end{tabular}

tested, the distribution of the average number of leukocytes according to the number of organisms phagocytosed is recorded. It is obvious that, as convalescence approaches, there is a definite increase in the number of cells in the "marked" column and a corresponding decrease in the number of cells found in both the "none to slight" and "definite" groups. 
TABLE II

The opsono-cytophagic power of the blood during the course of pertussis

\begin{tabular}{|c|c|c|c|c|c|}
\hline \multirow{2}{*}{ Patient } & \multirow{2}{*}{ Age } & \multirow{2}{*}{$\begin{array}{l}\text { Week } \\
\text { of } \\
\text { disease }\end{array}$} & \multicolumn{3}{|c|}{$\begin{array}{l}\text { Distribution of cells according } \\
\text { to the number of organisms } \\
\text { phagocytosed }\end{array}$} \\
\hline & & & $\begin{array}{c}0 \text { to } 4 \\
\text { organisms } \\
\text { "none to } \\
\text { slight" }\end{array}$ & $\begin{array}{c}5 \text { to } 19 \\
\text { organisms } \\
\text { "definite" }\end{array}$ & $\begin{array}{c}20+ \\
\text { organisms } \\
\text { "marked" }\end{array}$ \\
\hline Ru... & 15 months & $\begin{array}{l}\text { 1st } \\
\text { 2nd } \\
\text { 3rd } \\
\text { 4th } \\
\text { 5th }\end{array}$ & $\begin{array}{l}3 \\
0 \\
0 \\
0 \\
0\end{array}$ & $\begin{array}{r}22 \\
21 \\
0 \\
14 \\
5\end{array}$ & $\begin{array}{r}0 \\
4 \\
25 \\
11 \\
20\end{array}$ \\
\hline $\mathrm{Br} .$. & 18 months & $\begin{array}{l}\text { 2nd } \\
\text { 3rd } \\
\text { 4th } \\
\text { 5th }\end{array}$ & $\begin{array}{l}0 \\
0 \\
1 \\
1\end{array}$ & $\begin{array}{r}19 \\
19 \\
20 \\
9\end{array}$ & $\begin{array}{r}6 \\
6 \\
4 \\
15\end{array}$ \\
\hline McStr... & 2 months & $\begin{array}{l}\text { 2nd } \\
\text { 5th } \\
\text { 6th } \\
\text { 7th }\end{array}$ & $\begin{array}{l}\mathbf{0} \\
\mathbf{0} \\
\mathbf{0} \\
\mathbf{0}\end{array}$ & $\begin{array}{r}23 \\
15 \\
1 \\
8\end{array}$ & $\begin{array}{r}2 \\
10 \\
24 \\
17\end{array}$ \\
\hline $\mathrm{O}^{\prime} \mathrm{C} .$. & 2 years & $\begin{array}{l}\text { 3rd } \\
\text { 5th } \\
\text { 6th } \\
\text { 7th } \\
\text { 8th }\end{array}$ & $\begin{array}{l}0 \\
3 \\
0 \\
0 \\
0\end{array}$ & $\begin{array}{r}12 \\
14 \\
2 \\
13 \\
3\end{array}$ & $\begin{array}{r}13 \\
8 \\
23 \\
12 \\
22\end{array}$ \\
\hline Ka... & 9 months & $\begin{array}{l}\text { 4th } \\
\text { 6th } \\
\text { 7th }\end{array}$ & $\begin{array}{l}1 \\
1 \\
0\end{array}$ & $\begin{array}{r}24 \\
3 \\
4\end{array}$ & $\begin{array}{r}0 \\
21 \\
21\end{array}$ \\
\hline Ho.. & 6 years & $\begin{array}{l}\text { 4th } \\
\text { 5th } \\
\text { 7th }\end{array}$ & $\begin{array}{l}\mathbf{0} \\
\mathbf{0} \\
\mathbf{0}\end{array}$ & $\begin{array}{r}10 \\
12 \\
3\end{array}$ & $\begin{array}{l}15 \\
13 \\
22\end{array}$ \\
\hline
\end{tabular}

TABLE III

The degree of phagocytosis in relationship to the history of the disease

\begin{tabular}{|c|c|c|c|c|}
\hline \multirow{2}{*}{ Age } & \multirow{2}{*}{ 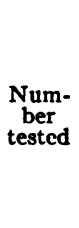 } & \multicolumn{3}{|c|}{$\begin{array}{c}\text { Distribution of the average } \\
\text { number of cells according to } \\
\text { the number of organisms } \\
\text { phagocytosed }\end{array}$} \\
\hline & & $\begin{array}{c}0 \text { to } 4 \\
\text { organisms } \\
\text { "none to } \\
\text { slight" }\end{array}$ & $\begin{array}{c}5 \text { to } 19 \\
\text { organisms } \\
\text { defi- } \\
\text { nite" }\end{array} \mid$ & $\begin{array}{l}20+ \\
\text { organisms } \\
\text { "marked" }\end{array}$ \\
\hline
\end{tabular}

NEGATIVE HISTORY OF PERTUSSIS

\begin{tabular}{l|r|r|r|r}
\hline 6 weeks to 6 months... & 8 & 8.1 & 13.6 & 3.2 \\
6 months to 2 years. . & 16 & 3.5 & 16.9 & 4.6 \\
2 to 5 years ......... & 7 & 1.7 & 11.9 & 11.4 \\
5 to 15 years ......... & 7 & 1.7 & 14.3 & 9.0 \\
\hline
\end{tabular}

POSITIVE HISTORY OF PERTUSSIS

\begin{tabular}{l|r|r|r|r}
\hline 6 weeks to 6 months... & 1 & 0 & 8 & 17 \\
6 months to 2 years... & 5 & 0.2 & 6.2 & 18.6 \\
2 to 5 years......... & 4 & 1.0 & 11.5 & 12.5 \\
5 to 15 years......... & 20 & 0.2 & 8.4 & 16.3 \\
\hline
\end{tabular}

Table II illustrates a similar increase in the phagocytosing power of the blood when tested on the same patient during the disease.

In Table III, the results obtained from studying a group of 38 infants and children with negative histories of the disease are compared with those obtained in a group of 30 who gave positive histories. It is apparent that, in general, the degree of phagocytosis is greater in the blood of those who had the disease, particularly in those under 2 years of age. In the older children ( 2 to 15 years) with negative histories, a high degree of phagocytosis was often observed. This suggests that the test is not entirely dependent upon

TABLE IV

A comparison of the opsono-cytophagic reaction of the blood in twenty mothers and their newborns in relationship to the history of pertussis in the mother

\begin{tabular}{|c|c|c|c|c|c|c|}
\hline \multirow{3}{*}{ Name } & \multicolumn{6}{|c|}{$\begin{array}{l}\text { Distribution of the polymorphonuclear neutrophiles } \\
\text { according to the number of organisms phagocytosed }\end{array}$} \\
\hline & \multicolumn{3}{|c|}{ Mothers } & \multicolumn{3}{|c|}{ Newborn } \\
\hline & $\begin{array}{c}0 \text { to } 4 \\
\text { organ- } \\
\text { isms } \\
\text { "none } \\
\text { to } \\
\text { slight" }\end{array}$ & $\begin{array}{l}5 \text { to } 19 \\
\text { organ- } \\
\text { isms } \\
\text { "defi- } \\
\text { nite" }\end{array}$ & $\begin{array}{c}20+ \\
\text { organ- } \\
\text { isms } \\
\text { "marked" }\end{array}$ & $\begin{array}{c}0 \text { to } 4 \\
\text { organ- } \\
\text { isms } \\
\text { "none } \\
\text { to } \\
\text { slight" }\end{array}$ & $\begin{array}{l}5 \text { to } 19 \\
\text { organ- } \\
\text { isms } \\
\text { "defi- } \\
\text { nite" }\end{array}$ & $\begin{array}{c}20+ \\
\text { organ- } \\
\text { isms } \\
\text { "marked" }\end{array}$ \\
\hline \multicolumn{7}{|c|}{ POSITIVE HISTORY OF PERTUSSIS } \\
\hline 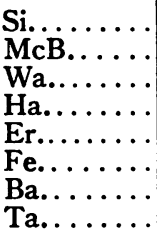 & $\begin{array}{l}0 \\
0 \\
1 \\
0 \\
0 \\
0 \\
0 \\
0\end{array}$ & $\begin{array}{r}2 \\
12 \\
10 \\
13 \\
7 \\
4 \\
6 \\
4\end{array}$ & $\begin{array}{l}23 \\
13 \\
14 \\
12 \\
18 \\
21 \\
19 \\
21\end{array}$ & $\begin{array}{r}0 \\
5 \\
0 \\
16 \\
24 \\
2 \\
0 \\
1\end{array}$ & $\begin{array}{r}4 \\
20 \\
17 \\
9 \\
1 \\
6 \\
12 \\
10\end{array}$ & $\begin{array}{r}21 \\
0 \\
8 \\
0 \\
0 \\
17 \\
13 \\
14\end{array}$ \\
\hline $\begin{array}{c}\text { Average } \\
\text { number of } \\
\text { cells }\end{array}$ & 0.1 & 7.2 & 17.6 & 6.0 & 9.9 & 9.1 \\
\hline \multicolumn{7}{|c|}{ NEGATIVE HISTORY OF PERTUSSIS } \\
\hline 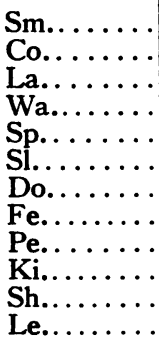 & $\begin{array}{l}1 \\
0 \\
1 \\
0 \\
0 \\
0 \\
0 \\
0 \\
2 \\
0 \\
2 \\
0\end{array}$ & $\begin{array}{r}12 \\
25 \\
21 \\
2 \\
11 \\
17 \\
20 \\
15 \\
17 \\
20 \\
22 \\
0\end{array}$ & $\begin{array}{r}12 \\
0 \\
3 \\
23 \\
14 \\
8 \\
5 \\
10 \\
6 \\
5 \\
1 \\
25\end{array}$ & $\begin{array}{r}8 \\
3 \\
8 \\
10 \\
14 \\
3 \\
7 \\
10 \\
18 \\
11 \\
6 \\
0\end{array}$ & $\begin{array}{r}12 \\
22 \\
17 \\
15 \\
10 \\
12 \\
14 \\
15 \\
7 \\
14 \\
19 \\
6\end{array}$ & $\begin{array}{r}5 \\
0 \\
0 \\
0 \\
1 \\
10 \\
4 \\
0 \\
0 \\
0 \\
0 \\
19\end{array}$ \\
\hline $\begin{array}{l}\text { Average } \\
\text { number of } \\
\text { cells }\end{array}$ & 0.5 & 15.1 & 9.3 & 8.1 & 13.5 & 3.3 \\
\hline
\end{tabular}


specific antibodies, for it is well known that, within certain limits, normal opsonins increase with age. Moreover, we have observed increased titers in the blood of febrile patients, and in patients after artificial heat therapy. These results probably depend, in part at least, upon a temporary increase in the so-called normal opsonins. Singer-Brooks and Miller (5) have observed similar results after the administration of nonspecific " respiratory" vaccines.

In Table IV, results of tests upon 20 mothers and their infants during the first 10 days of life are shown. It is apparent that, in general, the titer of the mother's blood is greater than that of the offspring and that a high titer in the newborn is almost invariably associated with a high titer in the mother. A high titer in the newborn is almost never associated with a low titer in the mother. This suggests that placental transfer of the opsonizing antibody occurs. Further investigation of this finding is in progress. When the averages of the cell distribution are compared, it is noted that the degree of phagocytosis is greater in the bloods of both mother and baby when there is a history of the disease in the mother.
SUM MARY

The opsono-cytophagic power of the blood increases during the course of pertussis. It is generally greater in those who have had the disease than in those who have not. Evidence is presented to suggest placental transfer of the antibody in certain instances.

\section{BIBLIOGRAPHY}

1. Veitch, R. M., A simple and rapid method of estimating the phagocytic power of different bloods. J. Path. and Bact., 1908, 12, 353.

2. Huddleson, I. F., Johnson, H. W., and Hamann, E. E., A study of the opsono-cytophagic power of the blood and allergic skin reaction in Brucella infection and immunity in man. Am. J. Pub. Health, 1933, 23, 917.

3. Bradford, W. L., The use of immune blood in whooping cough and its effect upon phagocytosis. $\mathrm{J}$. Pediat. (Proc.), 1936, 9, 117.

4. Kendrick, P., Personal communication.

5. Singer-Brooks, C., and Miller, J. J., Personal communication.

6. Zinsser, H., and Bayne-Jones, S., A Textbook of Bacteriology. Appleton-Century Co., 1934, 7th ed., p. 1063. 